\title{
Judicial Activism or Self-Restraint: Some Insight Into The Indonesian Constitutional Court
}

\author{
Radian Salman \\ Faculty of Law, Airlangga University \\ Surabaya, Indonesia \\ radian@fh.unair.ac.id
}

\begin{abstract}
The Constitutional Court of Republic of Indonesia is centralized judicial review institution which implements a posteriori and abstract control. Constitutional court decision often politically sensitive and involve important issues. On the one hand handing down strong decisions that uphold important constitutional principles can bring great benefits to citizens and can strengthen support for democracy but on the other hand, strong role of the court in judicial review tends to encroach increasingly on the territory of the law making institution. This article examines the decision of constitutional court in the framework of a tension between constitutionalism and democracy, especially from theoretical or conceptual approach. As result of examining its decisions, Indonesian Constitutional Court may reflect two characters; judicial activism as characterized by acting as law-maker and using policy in judicial decisions and/ or judicial self-restraint. Recent Indonesian experience shows that judicial review of legislation is not a simply of judicial control over law-making institution, as it brings tension in the context of power relations in the scheme of separation of power. Relationship between the court and legislature, in respective of judicial review, will culminate in the philosophy of the judiciary. However, as constitutionalism and democracy are virtue, decisions of the Constitutional Court in judicial review should create mode of selflimitation within the framework of the principle of separation of powers.KeywordsBank; corporate governance; new perspective; basel.
\end{abstract}

Keywords-Constitutional Court; Judical Review; Judical Activism; Judical SelfRestraint.

\section{INTRODUCTION}

Judicial review has its roots on the principle of constitutional supremacy and constitutionalism. From the constitutional supremacy point of view, the any law under the Constitution shall not be contradictory to the Constitution. Therefore, there should be a mechanism to review the constitutionality of a law (the constitutionality of legislation). In constitutionalism perspective, the limitation of power is imposed. The limitation means that the absence of control mechanism on the legislature tends to the abuse of power, thus, the situation could contribute the possibility of making laws in contrary to the norms of the constitution (Marzuki 2010, p. 4) . On the other issue, the constitutionalism also means the recognitions of the human rights which have consequences for the enforcement of those rights by an independent judiciary, including the protection from existence of Laws that could harm the human rights. Although judicial review stands on the principle of constitutional supremacy and constitutionalism, in a constitutional democracy state, the judicial review always raises the normative question of two things; namely institutional legitimacy and how these institutions should be run. Furthermore, in the context of constitutional democracy, the judicial review has placed the Constitutional Court as a superior institution in control relations of the branches of legislative and executive power.

At the national level, views and concerns arise as a response to some of the Indonesian Constitutional Court decisions in judicial review 
such as: the exclusion of (non-application) of Article 50 of the Constitutional Court Act to review constitutionality Law No 14, 1985, but the Court did not decide the unconstitutionality of the article (Decision No. 004/PUU-I/2003); the Court delivered ultra petita decision and ruled on its own interests as well as unanimously interpreted that the Constitutional Court judges were not within the scope of the Judicial Commission supervision on the judicial review of the Judicial Commission Act (Decision No. 005/PUU-IV/2006); decision that contains policy to delay the invalidity of Article 53 of Law No. 30 Year 2002 on the Corruption Eradication Commission, even though, declared unconstitutional (Decisions No. 012-016019/PUU-IV/2006); and the decision contains norm-making as in popular case of "the used of ID cards in the Presidential Election".(Decision No. 102/PUU-VII/2009).

Such decisions generates fundamental problems concerning on the proper role of judiciary in the context of the framework of the institutional relationship within the constitutional law system, in accordance to the principle of separation of powers, particularly the authority of the Court in conducting a proportional judicial review in democracy. The strengthening of the judiciary branch brings consequences to the development of the role of judicial power to conduct further justice that overstepping powers and authorities, which has been the political domain of the executive power and legislative power (Koopmans 2003). To response such phenomenon, the German law Journal (2007), in particular publishes a controversial provocative issues, namely the coup on the courtroom (coup de'tat in the courtroom), with the main article from Alec Stone Sweet, describing the phenomenon of widespread and more powerful judiciary. Meanwhile, Hirschl (2004, h.3) describes such phenomon as "juristochracy," and Schepelle calls it as a 'courtocracy' where in different countries, the constitutional reform has transformed the power of the representative bodies to the judicial institution by the recognition of human rights in the Constitution and the mechanism of judicial review. The transformation in this case, has the meaning that the important public policies which originally was in the hands of the elected-agencies and made on the basis of consensus or majority decision was to be switched to the judiciary (Bugarij 2001, Bell 1983). Such transformation was also shifting the concept of democracy, from the 'majority rule' to the 'real-democracy', namely, the constitutional democracy as a shift of the "democracy governed predominantly by the principle of parliamentary sovereignty" (Hirschl 2004).

To this extent, the judicial review, the interpretations and the Constitutional Court decisions on the constitutionality of the Laws have the complexity of conceptual in the Constitutional Law. At this point, Judicial review often produces two possibilities, namely: the tendency of judicial activism or judicial self restraint. This article is about to describe the Constitution Court of Indonesia into two discussion of the judicial activism and judicial self-restraint to get on the proposal on the proportional role of the Indonesian Constitutional Court in the judicial review

\section{The Idea and the Development of The Judicial Review}

Understanding the judiciary as a choice of institution for conducting judical review should begin with the idea of the review on constitutionality of the Laws. The constitutional law experts generally refer to an explanation of the judicial review that moves from the Supreme court's decision of the United States in the case of Marbury V. Madison (5 U.S. 137 (1803). The decision was actually the concrete case related to the issuance of the appointment letter of the peace justice, William Marbury etc, in the end of the President John Adams administration. This decision was a judicial review due to review of the Judiciary Act (1789) section 3. Justice John 
Marshall in the decision stated: " a law repugnant to the Constitution is void; and that courts, as well as other departments, are bound by that instrument". The controversy of Marbury V. Madison's decision was not purely as the discovery of John Marshall, even though US model of judicial review becomes an example and a model for many democratic countries. The Decision, in that case, which states that the Constitution is either a superior, Paramount law, unchangeable by ordinary means, is basically the idea of position of norms, which the Ancient Greek distinguished as "nomos" and "psphisma". "Nomoi" in the modern Constitution, in some aspects, is the Constitution in present days, as the substances are the state organization and procedures to make and change 'nomoi' need complex and difficult process. Whilts, "psphisma" should not be contradicted to "nomoi". In the medieval ages, the Roman law recognized the principle of "legibus solutus ", which means that the King is above the law and therefore is immune to the law. However, in its evolution, the Roman Law recognized the principle that the King is subject to the Law, which was known as " princeps legibus tenetur ". Furthermore, in the middle ages, the natural law school distinguished two types of norms, the jus naturale, which was superior and jus positivum, which applied if not conflicted to the jus naturale. The such norms doctrine has put the framework of the institutional method in order to determine whether or not the norms are contrary to others within the hierarchy of norm system. The French Constitution of 1799, 1852, 1946 and 1958 has set the control over the norms in the Legislation, though, it is always exercised through the political and non-judiciary mechanism. However, the practice of norms control by the judiciary had actually taken place in the long-regime of French, where the Parlement, as the Highest Court was only established in some of the cities in France, stated that they have the authority to conduct judicial review of all the rules against "the fundamental laws of the realm" (Kommers 1976, p.52-64; Cappelletti 1970, p. 1017-1053). French, starting on revolution era of 1789 , had chosen a strict model separation of powers which did not grant the Court to have certain power to intervene the parliament as lawmakers (Riem: 22004). Since then, Pasquino (1998, p. 45) called it as the "French ideology", which means that "in the representative government parliament is the only legitimate organs to express popular will". However, in the development, the French Constitutional Amendment of 1958 that occured in 2008 brings the idea of Kelsenian Judicial Review of a posteriori, which later was called by Fabrini as Kelsen in Paris (Fabrini 2008). Having known as the abbreviation QPC (question prioritaire de constitutionnalité), the then new article, namely article 61-1 of the 1958 Constitution marks the adoption of judicial review on the constitutionality of Laws in France:

'If, during proceedings in progress before a court of law, it is claimed that a statutory provision infringes the rights and freedoms guaranteed by the Constitution, the matter may be referred by the Conseil d'Etat or by the Cour de Cassation to the Constitutional Council, within a determined period. An Institutional Act shall determine the conditions for the application of the present article'.

In the UK, the opinion Sir Edward Coke's in the decision of the case Dr. Bonham, 1610, expressly stated that Act of Parliament "against common right and reason is void". The decision marked the supremacy of the common law and the Magna charta against the Law made by the Parliament. The Coke's decision brought influence in some of the British states colonies, including the United States as Justice Holmes stated that the decision of the case Dr. Bonham was "one of the foundations for the American constitutional law." Still in the context of the UK Constitutional system, on the 18th century, the Privy Council (advisory board of the Kingdom) was given the authority to annul law of British colonies on the grounds of contradiction to the law made by the British Parliament or contradiction to the common law. On the 
convention (Constitution) of Philadelphia of 1787, some delegations and the federalist urged the need for judicial review institution as a consequence of a written Constitution and the principle of separation of powers, especially independent of judiciary. The practice of judicial review in the United States before the decision of the case of Marbury has also taken place, such as the decision in the revolution era on the case of Holmes V. Watson (1780), as the first judicial review and ten pounds Act cases (1786-87) which both of which relates to review the jury trial in the US justice systems. Although the Continental legal tradition recognized the doctrine of the hierarchy of norms, the mechanism of judicial review by the Court institutions did not develop untill the emergence of "constitutional review" in the Constitution of Austria 1920.

The stagnation of the judicial review institution in some European Continental countries with the most systems of government were parliamentary, as well as the history of monarchy, had influenced the doctrine of separation of powers and the system of French parliamentary, especially the principle that the Parliament was the only legitimate institution in running the will of the people. Malberg (Pasquino; 1998), stated that the will of Parliament was the only reflection of the will of the people and because of the will of the people is sovereign, therefore, there is no benefit to control the sovereign. In line with the raising human rights awareness, constitusionalisation of human rights, democracy and the up-down of power of the parliament and strengthening of the Constitutional supremacy, the judicial review has developed, and therefore was identified to be one of the elements of constitutionalism. In the context of human rights, Hirschl (2004) found three categories of constitutional factors of human rights and the judicial expansion. The first category, constitutionalisation occured as part of the democratic transitions and market economy, as shown from the experience in Eastern Europe countries. Second, constitutionalisation as a product of the democratic transitions and third, constitutionalisation as a result of fundamental changes of the political regime or economic as shown on the experience of Canada in 1986, Belgium in 1985 and new Zealand in 1990. In Indonesia, the constitutionalisation of human rights clearly visible on the increasing of the provisions of human rights as a result of the Amendment to the Constitution of 1945. Koopmans (2003, p. 31) stated that such situation as the "constitutional model" as opposed to the "parliamentary model" because the Parliament is no longer "sovereign" or "Supreme" since the legislation should not be contrary to the Constitution (Tushnet, 2012, p. 2 ). On the basis of the separation of power, the nature of reviewing Laws remain as a form of the judicial intervention against the law making power. Therefore, the judicial review is considered having political aspects. In the Kelsenian perspective, the ordinary courts judges, such as a judicial review in the United States, should not conduct judicial review since the judges shall accept and apply the Laws made by the representative bodies.

The Austrian model of constitutional review also referred to the "Continental model", "a centralized model" or "kelsenian model" which is based on the model developed by Kelsen in 1919 becomes an institution which is considered to be able to answer the question within the doctrine of separation of power. Kelsenian model, according to Besselink (2013, p. 30), provides at least two interests institutional which touches upon the legitimacy of constitutional adjudication, namely: a. the division and balance of powers between the legislature, the executive and the judiciary, and $b$. the composition of constitutional courts. In the context of both interests, Besselink (2003) explained that the presence of the court placed as a model beyond Trias politica, since accordingly, the Court "has to supervise the constitutional boundaries between constitutional institutions, including those of the judiciary". This view is reflected 
from almost all models of the constitutional court in Europe, which is marked by the model of judges recruitments which has to involve the three branches of Trias politica scheme.

In the theoretical perspective, the Kelsenian model of judicial review can be seen from three arguments; first, the consequences of the doctrine of separation of power and the supremacy of the Laws (statutory law) in Continental Law tradition. Kelsen (2008, p.272), in the context of the US constitutional practice, clearly stated that "a judicial review of legislation is an obvious encroachment upon the principle of separation of power". The power of the Court to annul legislation is actually the legislative power, since the annulation of a law has the same character with the revocation of law by legislative. As a consequence of political aspects of judicial review on the constitutionality of law, the appointment of judges on constitutional court always reflects the involvement of political institutions (Cappelletti, $\mathrm{p}$ 1041) . Although, in the development of constitutional court in different countries, there are several variants method of recruitment process or the appointment of the constitutional court judges. However, the legislative branch always has a crucial role and even determinining. Harding and Leyland (2009, p. 16-18) identify four models in the judge appointment process of constitutional court, namely; 1). Representative bodies + President; 2). Representative bodies; 3) representative bodies + President + the Supreme court; and 4). A special Commission. In the last model, the special Commission which has nomination character or selection character, but the decision is in the hands of the representative bodies (the parliament).

For example and comparison, the 16 Constitutional Court judges of the Federal German, are chosen by Bundestag and bundesrat each 8 . The Constitutional court judges of Italy in total are 15 , each of $1 / 3$ are nominated by the President, the parliament and the Supreme court, where it is also the same as the Indonesian model. Second, the absence of doctrine "stare decisis". The absence of such doctrine has to be followed by the judges in their decisions which have been resolved earlier in the similar case, as in the tradition of "common law", has made the judicial review requires the special and single institution to ensure the consistency of the decision and the law enforcement. Third, inaccuracies of the Court (ordinary court) as the institution reviewing constitutionality. The judicial review is essentially a constitutional question which not only about the dimensionless of law enforcement (applying law), but also including the value and the views of the Constitution as the abstract and fundamental norms. Consequently, according to Besselink (h.33) , the meaning of specialized and centralized is including the judge qualification and expertises in term of the "constitutional professionalism" which have functions to avoid "the suspicion of being 'political'. The judicial review on the constitutionality of the laws by judges needs sensibility of discretionary than just an activity of interpretation. Therefore, the judicial review has essential character of legislative rather than purely a judicial. Furthermore, on the development of the judicial review, Romeu (2006) argued that there are five raison d'etre of the establishment of the constitutional court, namely: the distrust of previously appointed ordinary judges; uncertainty as to the relation of political forces, legal uncertainty resulting from adjudicatory institutions, the need of the federal arrangements; and imitation of similar Democratic experiences.

\section{Adjudication and Interpretation in the Judicial Review}

The essence of judicial review of constitutionality of the law is a constitutional adjudication activity. The constitutional adjudication is essentially how the court works against the constitution. In other words, adjudication is about how judges decide or 
should decide cases in constitutional adjudication. Based on the principle of the judicial independence and the principle of impartiality, judicial review will never put the role of judges merely as a mouthpiece of the Laws. The adjudication for the constitutional review on the Legislation is even more giving unimpeded role to the judges to not only judging whether or not the Law is contrary to the Constitution but also interpreting the Constitution in order to examine the constitutionality of the Law. Therefore, the interpretation becomes the key in the judicial review of law. D'Amato (1995, p. 1) argues:

"the way judges decide a case is informed by their own conceptions of what the law is not just what a statute might say, or a previous case might have held, but what the law is in the sense of how they should interpret those statutes or cases."

How the Constitution is interpreted depends on how thejudge's perspective in the constitutional adjudication. Schaefer (1996) stated:

"If [the judge] views the role of the court as a passive one, he will be willing to delegate the responsibility for change, and he will not greatly care whether the delegated authority is exercised or not. If he views the court as an instrument of society designed to reflect in its decisions the morality of the community, he will be more likely to look precedent in the teeth and to measure it against the ideals and aspirations of his time".

According to Schaefer (1996), there are two stands regarding the position of judge in the constitutional adjudication. First, the passive stand tends to imply that other institutions have to take action or conduct changes. This first model has a tendency to a model of judicial selfrestraint and stands on the view of departmentalism. The second stand is the active stand on the ground that the judiciary is an important actor whose decision is an instrument for the community development. The result of this second stand is the model of active Court (judicial activism) based on principle of judicial supremacy in the constitutional adjudication. In the context of adjudication for the judicial review; it has always a political character since the judge does not only do the "law-finding" as Limbach (2001) said: "We must accordingly concede that judicial decision making is not only law-finding, but also also law-making. The judge creates law in the process of finding a decision. Adjudication thus always has a political dimension too ". Having regards that the interpretation is an inherent activity in judicial review, the most important and fundamental question in constitutional interpretation is how the constitution will be interpreted?. In other words, the judicial review does not merely about judging whether or not articles, clauses or verses in the Act are contrary to the Constitution, but even more applying the constitutional or constitutional principles. Therefore, judges shall also decide the meaning of the norms. At this point the constitution must always be interpreted to ensure that the legislation as a delegated-Constitution does not contradictory to the Constitution. Accordingly, in a constitutional adjudication, Justice Hughes states that 'a constitution is without meaning until the judges pour meaning into its provisions' (Montana and Ramaphosa; 2002, p. 13). One of the reasons of having constitutional interpretation is the constitution made in the period, momentum and context when the constitution is made. Consequently, the meaning of the constitution is not always the same as when it was made with its further development. If the meaning remains the same, then it requires at least a construction when being applied in judicial review. The third reason is that the dichotomist divides the interpretation of the constitution into two views: orginalism and nonoriginism.

The originalism as well as the nonoriginalism has its own reasons in the 
application. The arguments of those who agree to use originalism, according to Chemerinsky (are because: first the essence of textual or document interpretation has to be limited to the "specific text and its framer intentions". Chemerinsky (2002) quotes Ben Michaels as saying that "any interpretation of the Constitution that really is an interpretation .... Constitution originally meant. "On the issue of constitutional supremacy, when a judge takes an oath to uphold the Constitution, the judge swears" ... to carry out the intention of its framers ". In this first reason, the constitution is considered as a "binding contract", so it is not to be distorted by the will of its framers. The second reason is that originalism limits the power of judges as the "unelected agency" in democracy. For this reason in the American context and in the context of democracy, it is based on the principle that decision making of public policy must be done by those who are accountable to the electorate. The consequence in this matter is that all public affairs must be seriously and continuously debated in institutions with the electoral mandate, not by a judge who has no electoral basis.

On the contrary, the non-originalist advocates put forward reasons, first; the development of the constitution can be done through the interpretation and not solely through the amendment. The mechanism of the constitutional amendment which always requires a rigorous mechanism tends to make the constitution difficult to be changed. Second, the intent of the framers of the Constitution varies greatly and in the practice of constitutional drafting, the person or particular group chosen as the authoritative party in determining the intent to draft the provisions of the constitution not only means that there is one purpose otherwise many and possibly for the conflicting reasons when agreeing to a certain provision as the content of the constitution.

The originalism and the non-originalissm are the two main approaches to constitutional interpretation. The method used in interpretation can be varied as it is the method of legal interpretation in general. The originalism and the non-originism are the instruments to analyze whether judicial review goes beyond the limits of separation of powers as one element of constitutionalism and whether it goes beyond constitutionalism. From the starting point, the originalism and the non-originalism delivers the choice of methods in interpretation, both constitutional interpretation and legal interpretation, i.e. whether to use textual, historical or systematic methods of interpretation. Furthermore, the originalism and the non- originalism can also be used to indicate whether or not the Constitutional Court has exceeded the limits of democracy in the sense that lawmakers are mandated by the people to perform the functions of the public will. Especially in the context of the Constitutional Court of the Republic of Indonesia, what method is to be used for interpretation is completely the territory of judge's discreation to decide (Decision No. 005 / PUU-IV / 2006)

\section{Constitutional Interpretation: Judicial Supremacy, Departementalisme and Popular Constitutionalism}

According to Bagir Manan (2010, p.8-11), the judge has a very close relationship with the constitution, as can be seen from: First; relationships that are not only related to judging, but include interpreting as a means of actualization or up dating of the Constitution. Interpretation may be to narrow or expand the constitutional norms, so that the actualization of the constitution is part of the duties of judges because judges have the authority to 'to say what the law is' in concrete cases. Second; Judges can create new constitutional norms. Such relations may be demonstrated in constitutional practice in the United States, among others, by a decision in the case of Marbury v Madison and Brown v Board of Education. In judicial review, the relationship between the judiciary or the Constitutional Court and the legislator is a 
representation of two dichotomous tensions, namely constitutionalism and democracy with a single question of who is the most supreme in upholding the constitution. The question of who is most supreme in upholding the constitution must be seen from the perspective of the Constitutional Court as a guardian of the constitution in the judicial adjudication decisions of constitutionality of the law. The answer to that question, theoretically and praxis can be investigate into three perspectives: Supremacy of the Judiciary, Departementalism and Popular Constitutionalism.

a. Supremacy of the Judiciary

Judicial supremacy or jurisentric is actually a perspective and perception on position of the judiciary among other institutions in the constitutional system in terms of constitutional interpretation. Judicial supremacy means "Court is better suited to the task of principled constitutional interpretation than any other branch of government." (El-Haj; 2012) In a more moderate language, Whitthington (2007, P. 5) refers to it as a leadership in constitutional interpretation." This concept places the judiciary as a sole and monopolistic institution in the interpretation of the constitution so that other branches in the constitutional law system must in conformity with judicial exegesis. Judicial supremacy occurs when there is a "deference" (humble and respect) attitude from other branches, as Whitthington (2002, P. 784) asserts:

"Judicial supremacy requires judgment of the Court, even when other government officials think that the Court is substantially wrong about the meaning of the Constitution and in the circumstances that are not subject to judicial review."

In this issue, Cooper v. Aaron is a landmark decision affirming the US Supreme Court as constitutional interpreters (Adler 2006, p. 719). The case originated from a state governor making a school segregation policy on the ground of race (skin color). Although there has been decision of Brown v. Board of Education, but the Governor assumes that the decision of the case is binding until the state makes the opposite law so that the decision in the case of Brown v. The Board of Education is not binding on the state. Not just the issue of school segregation on the basis of race, Cooper v. Aaron raises the legal issue of whether the state is bound by all decisions of the US Supreme Court. Finally the decision of the case places the Supreme Court as a supreme institution, as clearly stated " "the federal judiciary is supreme in the exposition of the law of the Constitution" and further that an "interpretation of [the Constitution] enunciated by th[e] Court. . . is the supreme law of the land." This ruling according to Adler means" Supreme Court ruling on constitutional matters binds the world, not just the parties to the case" and as the court as ultimate interpreters, and therefore according to Whitthington (2002) other government officials are required to adopt..

Judicial supremacy in judicial review context is also supported by the general principles underlying the judiciary; namely the principle of the independence of the judiciary and the impartiality. Those two principles collide with a democracy that places electoral supremacy as the law maker. Electoral democracy that produces representative bodies is considered most appropriate in interpreting the laws it makes both the constitution and the law. Lord Irvine (2000, p. 11-12) called it as "pragmatic imperative", which means judiciary "... have considerably less expertise than the parliament, particularly on substantive matters of policy, so it should be 'that the authority [i.e. Parliament] itself should make such decisions because it is better equipped to do so "'. Another reason is the so-called 'democratic imperative', meaning "that the electoral system operates as an important safeguard against the misuse of public power by 
requiring many public authorities to submit themselves to the verdict of the electorate at periodic intervals" (Limbach, 2001). In the point of view of judicial supremacy, decisions of the Court in judicial review cases has a tendency for judicial activism. However, qualified judgments are key in maintaining the supremacy of the judiciary or at least making the judiciary credible. Jaegere et.al in the context of the judiciary as a deliberative forum warns that "key is the overall strength or robustness of the argument, and not only the political support of a particular political view enjoys" (De Jaegere, Beyers and Popelier).

\section{B. Departementalism}

The opposite of judicial supremacy is deparmentalism, which places the branches of government as equal institutions and each has the authority to interpret. Whitthington in the context of US experiences refers "our national experience teaches that the Constitution is preserved the best practices and determinations of the other branches,". Whitthington (2002, p. 784) then defines deparmentalism as "the most explicit and then perceived idea of the influence of the Depormentalism as" each branch, or department, of the government ". Clear and affirmed view on departmentalism came from 16th President of the United States of America Abraham Lincoln, in response to the decisions of Dred Scott's case: "If the policy of the Government on vital questions affecting the whole people is to be irrevocably fixed by decisions of the Supreme Court, the instant they are made in ordinary litigation between parties in personal actions the people will have ceased to be their own rulers" (Richardson 1841). Similar view were also presented by the $3 \mathrm{rd}$ President, Thomas Jefferson in the polemic of the Sedition Act of 1798: "[N] othing in the Constitution has given [judges]. . . A right to decide for the Executive, more than to the Executive to decide for them. Both magistracies are equally independent in the sphere of action." (Ford 1897). Criticism of the departmentalism is the possibility of legal chaos and the disrespect of the constitution because each has a basic authority and basic interpretation of the constitution. Hence the skeptical response to the views of departmentism is that the branches of state power can claim the truth of the interpretation of the constitution (Lawrence; 1992).

The debate between judicial supremacy and departmentalism is always manifest in systems that recognize and embrace the judicial review of legislation. This is also apparent in the constitutional adjudication by the Constitutional Court of the Republic of Indonesia. It is obviously seen in the amendment of Constitutional Court Act (Law No. 8 Year 2011), Article 57 Paragraph 2 (a) stipulated to restrict the decision model of the Constitutional Court so as not to ultra petita, should not create decision imposing other branches to make law and the Court is not allowed to make legal norms in its decision.

Comparing the concept of judicial supremacy and departmentalism, it can be concluded that judicial supremacy has a tendency towards judicial activism, while departmentalism correlates with judicial restraint or selflimitation models. Asshiddiqie (2011)offers moderate view upon the two poles in the constitutional interpretation. He proposes to use term "the final interpreter of the constitution", instead of "the sole interpreter" . Therefore, the Supreme Court of the United States of America and likewise with the Constitutional Court of the Republic of Indonesia are not the only institutions that can interpret the Constitution, but all interpretations by other branches of power are not final. 


\section{Popular Constitutionalism}

Judicial supremacy considers that the judiciary is the most appropriate institution to be attached to the task of interpreting the constitution, while departmentalism acknowledge that every branch of power has an equal position and authority to perform constitutional interpretations, especially within its sphere of power. Popular constitutionalism is an idea that puts "people" as central in relation to the constitution. This concept is developed in US inspired by preamble of US Constitution "We the People", with the main proponent Larry D. Kramer, primarily in his work "The People Themselves: Popular Constitutionalism and Judicial Review." The central position of the people in relation to the constitution, Particularly the US context as stated by Kramer (2004, p. 8) that "American constitutionalism assigned ordinary citizens a central and pivotal role in implementing their Constitution. Final interpretive authority rested with "the people themselves," and courts no less than elected representatives were subordinate to their judgments ". Kramer's view moved from a conception of constitutionalism that differed in meaning in its development which then he considered that the final interpreter of the constitution was the people themselves. In detail Kramer (2007) defines popular constitutionalism as follows:

"Constitutionalism in the Founding era was different. Then, power to interpret (and not just the power to make) constitutional law was thought to reside with the people. And not theoretically or in the abstract, but in an active, ongoing sense. It was the community at largenot the judiciary, not any branch of the government-that controlled the meaning of the Constitution and was responsible for ensuring its proper implementation in the day-to-day process of governing. This is the notion I labeled "popular constitutionalism"-to distinguish it from "legal constitutionalism" or the idea that constitutional interpretation has been turned over to the judiciary and, in particular, to the Supreme Court."

The popular idea of constitutionalism faces practical problem, namely the question of form of institutionalization of this idea, how to exercise constitutional interpretation by the people" , and how "people" can be trusted as a final interpreter of the constitution. Although there are questions about how the implementation of this conception, popular constitutionalism essentially denies the supremacy of the judiciary by recognizing departmentalism but putting the final interpreter on the "people" (Pozen; 2010) . To make it easier to understand the different concepts of supremacy of the judiciary, departementalism and Popular Constitutionalism, Pozen (2010) explains in the following:

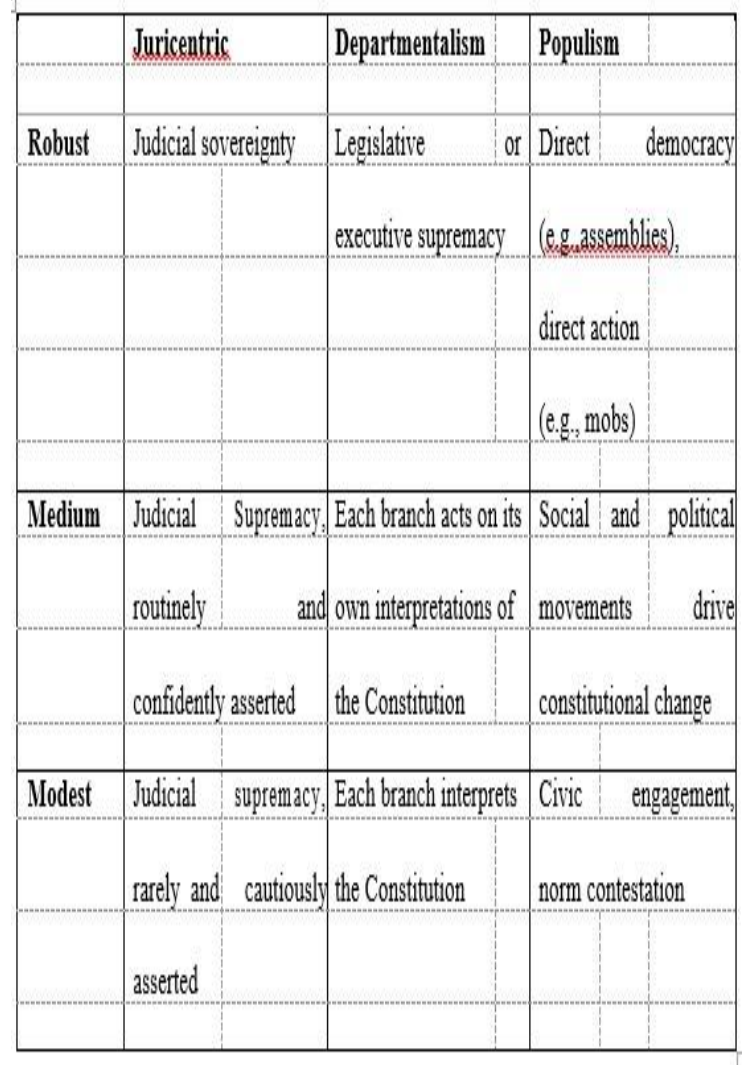

Popular constitusionalism in academic discourse in Indonesia in relation to the 
Constitutional Court has not received response and discussion compared with the issue of judicial supremacy and judicial activism. But when looking at the table above, the symptoms of populism has been going on since the constitutional reform. For example, in the context of constitutional amendment, civil society encourages to establishe constitutional commissions as antithetical to MPR institutions that are considered elitist and do not reflect the representation and aspiration in constitutionmaking. Similarly we find systematic efforts from group of socities to examine decisions of the Constitutional Court reflecting civic engagement to influence the Constitutional Court in ruling judicial review cases.

\section{Judicial Activism Vs Judicial Self Restrait}

Butt (2006) considers that Indonesian Constitutional Court can be categorized as adherents of judicial activism, at least under the first two periods of court leadership, in which Butt equates Court activism with South Korean Constitutional Court. Two aspects in his view that indicate judicial activism, namely the first "active in the sense that it actually performs its function and invalidates statutory provisions - or even entire statutes.-as it deems necessary ". Secondly, it is shown from the consistency of "rejection of legislative attepts to restrict what it believes to be its constitutionally mandated constitutional review of jurisdiction and its theories at its boundaries of its jurisdiction".

Referring to the opinion of the Butt, the issue of judicial activism and the restriction of the judiciary must depart from the concept of originalism and non originality. Since 1990 the term "judicial activism" and "judicial activist" has been discussed in 3,815 articles and reviews in various journals of law. Judicial activism and judicial restraint, relating to "how well they realize the judicial role of bridging the gap between law and society's changing reality and the role of protecting the constitution and its values The term judicial activism was first introduced by Arthur Schlesinger in January 1947 in Fortune magazine. Black's Law Dictionary defines judicial activism as follows:

A philosophy of judicial decision-making whereby judges allow their personal views about public policy, among other factors, to guide their decisions, usually with the suggestion that adherents of this philosophy tend to find constitutional violations and are willing to ignore precedent.

Justice Barak (2006, p. 271), defines judicial activism as:

is the judicial tendency - conscious or unconscious - to achieve the proper balance between conflicting social values (such as individual rights against the needs of the collective, the liberty of one person against that of another, the authority of one branch of government against another) through change in the existing law (invalidating an unconstitutional statute, invalidating secondary legislation that conflicts with a statute, reversing a judicial precedent) or through creating new law that did not previously exist (through interpreting the constitution or legislation, through developing the common law).

Criticism or a negative view upon judicial activism is because judges are deemed to use their judicial discretion contrary to general principles, such as the principle that judges only exercise the function of applying laws made by legislators. Conversely the judge positioned himself to give consideration to the political, social, and economic policies even replace the position of legislator. Judges decide cases or legal disputes so that they do not become policymakers, because "Judges are well versed in the law but they are manifestly not the best equipped" to translate "community values into constitutional policies ...". 
Judicial activism is not always negative impression. The following reasons are positive views of judicial activism, among others: first, that judicial activism is a manifestation of checks and balances. Therefore the judiciary does not simply annul legislation but also ensures that the product of the legislature is in accordance with the constitution. Secondly, judicial activism is important in upholding of human rights. The assumption is that the law is an arrangement that occupies various aspects not only of government organizational institutions but also of human rights. Therefore, judicial activism is needed to guarantee human rights, especially constitutional rights recognized and guaranteed by the constitution. Types or forms of judicial activism vary, among others (Slattery 2013), "importing foreign law to interpretation of the constitution; Elevating policy considerations above the requirements of law; Discovering new "rights" not found in the text, and bending the text of the Constitution or a law to comport with the judge's own sensibilities, to name just a few" . Kmiec (2004, p141-147) identified the manifestations of yudisiil activism as follows: a. Striking Down Arguably Constitutional actions of Other branches; b. Ingnoring precedent; c. Judicial legislation; and d. Result oriented judging

The opposite of judicial activism is the judicial restraint defined as (Posner 1996, p. 314) "'the judicial tendency - conscious or unconscious - to achieve the proper balance between conflicting social values by preserving existing law rather than creating new law ". Posner (2012, p. 520-521) classifies three aspects of judicial restrictions; deference, reticence and prudence. "Deference" which literally means "relief" and "respect" means "avoiding contrasts with the decisions of other branches of government," while reticence means silence is defined as "assumption that judges should not be making policy decisions". Both of these are attitudes based on the consideration of the legitimacy of judicial decisions in the democratic system. The prudential means the judge "should avoid making decisions that may well impair their capacity to make other decisions". In the context of constitutional adjudication, there is a constitutional restraint, by: (1) is motivated by notions of comparative institutional competence, (2) by respect for the elected branches of government, although that respect is sometimes based on a belief that legislatures do policy better than courts do, which is a form of judicial modesty. From the point of view of the restrictions of the judiciary, the court is deemed to have no legitimacy if judges use judicial review to replace the ideas of society's policies and virtues established by the people's representative bodies elected by the people. Replacing democratically elected bodies is considered to harm the commitment to democratic governance. The practice of this restraint can be found in the dissenting opinion of Justice Frankfurter in the case of Trop v Dulles, (356 US 86, 1958). Frankfurter says:

The legislation is the result of an exercise by Conggress of the legislative power vested in it by the Constitution, and of the exercise by the President of his constitutional power in approving a bill and thereby making it ' $a$ law'. To sustain it is to respect the action of two branch of our government directly responsible to the will of the people and enpowered the Constitution to determine the wisdom of legislation. The awesome of this Court to invalidate such legislation, because in practice it is bounded only by our own prudence in discerning the limits of the Court's Constitutional function, must be exerciced with the utmost restraint.

Judicial activism and judicial self-restraint approaches in the interpretation of the constitution have been relatively criticized. This means that it is no longer relevant to draw tight boundaries to totally reject one of them. Therefore, the most important of the judicial review is the adequate "legal reasoning" of the decision. However, as matter of fact, I identified some decisions of Indonesian Constitutional 
Court resonate the judicial activism: policy in judicial decision.; decision formulating legal norms, and decision expands the power the constitutional court.

\section{Proposal for Proportional Role of the Constitutional Court in the Judicial Review}

On the basis of constitutionalism and democracy, this article tries to formulate the proportional role of the Constitutional Court in the judicial review of the Laws as follows:

First, the classic and general principle of the annulment of the law is because it is clearly contrary to the Constitution (clear mistake). With such principles, judicial review emerges because of a real error in the contents of the legislation that contradict to the Constitution. The clear mistake concept could be used on expressly verbis against the constitution. However, the principle restricts that "clear mistake" only results in the annulment, and has no consequence to regulate.

Secondly, on the constitutional issues that clearly delegated entirely to the legislator, which is often referred to as an open legal policy, the Constitutional Court should not overstep the legislative-regulatory zone as a result of the annulment. This means that the Constitutional Court retains the power to annul, but the Constitutional Court has no right to regulate (making law), since the constitution clearly grants the power to the legislator. If the Constitutional Court is oriented to make Laws, it is not necessary to make a decision with a conditional interpretation model or the formulation of new norms, but the Court may only provide sufficient guidance on certain constitutional issues in the consideration of its decision. Moreover, the lawmakers will refine or make a new law with the suggestions according to the Court's decision. As a consequence of the third point, in the decision, the Constitutional Court shall explicitly submit its suggestions to the legislator.
Thirdly, as a consequence of the hierarchy of Laws and the consequences of the separation of powers, the Constitutional Court's decisions may not contain imperative order to lawmakers to enact law and to make a law with any substances determined by the Constitutional Court. However, this is different from the South African Constitutional Court which indeed in the Constitution authorizes the Constitutional Court to review the bill so that the Constitutional Court's decision becomes the basis of consideration of the substance of the law in the law making process. Similarly to the South African Court, the Hungarian Constitutional Court's authority is ex officio authorized initiating a case in situation of omission by the legislature. Therefore, its decision enforce the legislator to apply the decision in the law making process. The 1945 Constitution has separated powers to each of power holders, so the order to make law is directly derived from the Constitution and not from the Constitutional Court decision. The Constitutional Court's decision only resulted to be followed-up, but not an order for the legislator.

Fourth, the legitimacy process in the separation power schemes should be part of the Constitutional Court's procedures. Especially if the judicial review of the law is a form of deliberative democracy conducted by the Constitutional Court, then the principle of all parties views and opinions must be heard shall be actually done. This principle takes precedence over the legislators, so it is not appropriate to review legislation without hearing any statements from the legislator even though by reason of urgency. In the cases referred to as the use of the ID cards and in any similar cases such as the use of the right to vote, without hearing the statements of the legislator is a violation of the principle of the audi et altera partem. 


\section{REFERENCES}

[1] Adler, Matthew D., Popular Constitutionalism and the Rule of Recognition: Whose PracticesGround U.S. Law?, 100 NW. U. L. REV. 719, 760 (2006).

[2] Besselink, Leonard F.M., The

Proliferation of Law and Constitutional Adjudication, How American Judicial Review Came to Europe After All, Utrecht Law Review, Volume 9, Issue 2 (March) 2013,

[3] Bugarij, Bojan., Courts as Policy-Makers, Lessons from Transition, Harvard International Law Journal, Vol. 42 No.1, Winter, 2001.

[4] Butt, Simon Andrew., Judicial Review In Indonesia: Between Civil Law And Accountability? A Study Of Constitutional Court Decisions 20032005, Dissertation, Department of Law, Melbourne University, December 2006.

[5] Cappeletti, Mauro., Judicial Review in Comparative Perspective, California Law Review, Vol 58, No. 5 (October 1970).

[6] D'Amato, Anthony., Analytic Jurisprudence Anthology, Anderson Publishing Co., Cincinnati-Ohio. 1995.

[7] El-Haj, TabathaAbu., Linking the Questions: Judicial Supremacy As a Matter of Constitutional Interpretation, Washington University Law Review Washington University Law Review, Vol. 1312.

[8] Fabbrini, Federico., Kelsen in Paris: France's Constitutional Reform and the Introduction of A Posteriori Constitutional Review of Legislation, German Law Journal Vol. 09 No. 10.

[9] Ford, Paul Leicester (ed.), Letter to Abigail Adams (Sept. 11, 1804), The Writings Of Thomas Jefferson 311, New York, G.P. Putnam's Sons 1897.

[10] Harding Andrew and Leyland Peter (Ed)., Constitutional Court: A Comparative
Study, Wildy, Simmons \& Hill Publisihing, England, 2009.

[11] Hirschl, Ran., Towards Juristocracy, The origins and consequences of the Constitutionalism, Harvard University Press, United States of America, 2004.

[12] Hirschl, Ran, The Political Origins of Judicial Empowerment Through Constitutionalization: Lessons from Four Constitutional Revolution, Law and Social Inquiry, Vol 25, No. 1 (Winter, 200).

[13] Hoffmann-Riem, Wolfgang, Two Hundred Years of Marbury v. Madison: The Struggle for Judicial Review of Constitutional Questions in the United States and in Europe, German Law Journal No.6, 685, 687 (2004).

[14] Jutta Limbach, The Concept of Supremacy of the Constitution, The Modern Law Review, Volume 64 No. 1, January 2001

[15] Kmiec, The Origin and Current Meanings of "Judicial Activism" California Law Review, Vol. 92, No. 5 (Oct., 2004).

[16] Kommers, Donald P., Judicial Review: Its Influence Abroad, Annals of the American Academy of Political and Social Science, Vol. 428, The American Revolution Abroad, (Nov, 1976).

[17] Kelsen, Hans., Judicial Review of Legislation: A Comparative Study of The Austrian and the American Constitution, The Journal of Politic, Vol. 4 No. 2 (May, 1942).

[18] Kramer, Larry D., The People Themselves: Popular Constitutionalism and Judicial Review, Oxford University Press, Oxford, 2004.

[19] Man": James Madison, Popular Constitutionalism, and the Theory of Deliberative Democracy, 41 Val. U. L. Rev. 697, 2007.

[20] Lawrence, KS, Contest for Constitutional Authority: The Abortion and War Powers Debates, University Press of Kansas, 1992. 
[21] Manan, Bagir., 'Penafsiran Sebagai Bentuk Penemuan Hukum', Makalah, 2011.

[22] Marzuki, M. Laica., Konstitusi dan Konstitusionalisme, Jurnal Konstitusi Vol. 7 No. 4 Agustus 2010.

[23] Pasquino, Pasquale., Constitutional Adjudication and Democracy. Comparative Perspectives: USA, France, Italy. Ratio Juris. Vol. 11 No. 1 March 1998.

[24] Pozen, David., Judicial Elections as Popular Constitutionalism,Columbia Law Review, Vol., November 2010.

[25] Richardson, James D. (ed.), A Compilation Of The Messages And Papers Of The Presidents 1789-1897. First Inaugural Address (Mar. 4, 1861),

[26] Romeu, Francisco Ramos, The Establishment of Constitutional Courts: A Study of 128 Democratic Constitutions, Review of Law and Economics Vol. 2 Iss. 1 (2006)

[27] Schaefer, Walter V., Precedent and Policy, University of Chicago Law Review: Vol. 34: Iss. 1.

[28] Slattery, Elizabeth H., How to Spot Judicial Activism: Three Recent Examples, Legal Memorandum No. 96, June 13, 2013.

[29] Whitthington, Keith E., Political Foundations of Judicial Supremacy: The Presidency, the Supreme Court, and Constitutional Leadership in U.S. History, Princeton University Press, New Jersey, 2007.

[30] Whittington, Keith E., et. al. (ed), The Oxford Handbook on Law and Politic, Oxford University Press, USA, 2009.

[31] Ziyad Montana \& Cyril Ramaphosa, Constitutional Law: Analysis and Cases, Oxford University Press, Oxford, 2002 